\title{
ЛИЧНЫЕ КАЧЕСТВА ДЕВОЧЕК-ПОДРОСТКОВ, ЗАНИМАЮЩИХСЯ ВОЛЕЙБОЛОМ
}

\author{
Ясыбаш Павел Афанасавич \\ преподаватель физической культуры \\ Гимназия А.С. Пушкина
}

\begin{abstract}
Аннотация: в статье рассмотрены личные качества девочек-подростков, занимающихся волейболом. Особенность заключается в непостоянстве характеристик данных категорий, их уникальности для каждого ребенка ввиду относительно разнящегося темпа физического и психического развития девочек-подростков. Для воссоздания более полной картины будем далее рассматривать «мотивационное образование», включающее в себя, как мотивы, так и потребности, ценности, цели, установки, социальные и природные фобии, свойственные девочкам данного возраста и способные влиять на их самоопределение и дальнейшее развитие.
\end{abstract}

Ключевые слова: девочки-подростки на занятиях в секции по волейболу, физическое и психическое развитие девочек-подростков, продуктивная активность.

\section{PERSONAL QUALITIES OF TEENAGE GIRLS, ENGAGED IN VOLLEYBALL}

\section{Yasybash Pavel Afanasievich}

\begin{abstract}
: the article examines the personal qualities of teenage girls engaged in volleyball. The peculiarity lies in the variability of the characteristics of these categories, their uniqueness for each child due to the relatively different pace of physical and mental development of teenage girls. To recreate a more complete picture, we will further consider "motivational education", which includes both motives and needs, values, goals, attitudes, social and natural phobias peculiar to girls of this age and capable of influencing their self-determination and further development.
\end{abstract}


Keywords: teenage girls in the classroom in the volleyball section, physical and mental development of teenage girls, productive activity.

Исходя из физических, психических и социальных особенностей девочекподростков, а также требований к освоению техники и тактики игры волейбол, необходимо выявить потребностно-мотивационную базу, основываясь на которой можно привлечь к занятиям данных детей, удержать их в секиии, направить на достижение спортивных результатов, получить сплоченную команду, воспитать личностей. Для воссоздания более полной картины будем далее рассматривать «мотивационное образование», включающее в себя, как мотивы, так и потребности, ценности, цели, установки, социальные и природные фобии, свойственные девочкам данного возраста и способные влиять на их самоопределение и дальнейшее развитие.

Особенность заключается в непостоянстве характеристик данных категорий, их уникальности для каждого ребенка ввиду относительно разнящегося темпа физического и психического развития девочек-подростков. Основной движущей силой, трансформирующей личность девочки, является гормональный фон, цель которого - превращение девочки в женщину. Влияние природных факторов в этом возрасте так велико, что противостоять им очень сложно и даже опасно для будущего физического и психического здоровья будущей женщины. Учитывая это и преследуя цель объективности изучении и достижения наибольшей эффективности дальнейшего педагогического воздействия, отношение к девочкам подросткового возраста должно быть, несомненно, природосообразным. Не случайно, решение большинства педагогических задач, в том числе в сфере физической культуры происходит наиболее эффективно, если использовать природные факторы развития, просто направляя их в нужное ученому русло.

Девочек подросткового возраста особенно беспокоит степень успешности в определении себя как человека женского пола, как человека, способного на достижение результатов в какой-либо деятельности, как интересной личности (В.Г. Казанская, 2008). Другими словами, для подростка еще непонятно, что он представляет из себя сейчас и будет представлять в будущем как жена и мать, как специалист в какой-либо из областей, как постоянно развивающаяся личность. Однако девочка-подросток ощущает, что она вступает именно в тот период своего развития, когда должна определить для себя и определить для 
окружающих свои возможные и желаемые роли. Данная неопределенность приводит к тому, что среди школьниц подросткового возраста можно наблюдать довольно высокий уровень фрустрации. Такие девочки раздражительны, в сложные для себя моменты нуждаются в эмоциональной поддержке больше остальных, возможно даже отчаяние по причине того, что они считают свои недостатки мало поддающимися исправлению, что еще раз указывает на важность удовлетворения их потребностей (Е.А. Артюхова, 2017).

С целью самоопределения подростки активно используют общение и различного рода деятельность - учебную, спортивную, общественную. Именно поэтому через привлечение детей подросткового возраста, опять же, к всевозможной продуктивной активности, решаются вопросы направленного педагогического воздействия на их личность. Важно, чтобы сохранялось сочетание деятельности и общения, или, так называемая, общественнозначимая деятельность (С.Л. Сидоркина, 2010). Одной из наиболее эффективных в этом плане является организованная физкультурная деятельность подростков (Е.М. Наумова, 2016). Однако следует различать предпочтения девочек-подростков, которые отличны от таковых у мальчиков в этом возрасте. И не случайно с началом среднего звена школы занятия физической культурой проходят отдельно для мальчиков и девочек.

Итак, рассмотрение потенциала различных видов физкультурных занятий для удовлетворения потребностей девочек подросткового возраста в общении и других видах активности можно выделить командные виды спорта. Одна из причин такого выбора - то, что в условиях принадлежности к референтной группе наиболее высокими темпами происходят процессы само- и социоидентичности. К слову, согласно исследованиям около $40 \%$ подростковдевочек подвержены постоянному ощущению тревоги. Параллельно с этим чувством часто присутствуют неуверенность в себе, уныние, боязнь трудностей и, как защитная реакция - наивность во избежание объективной оценки себя и своих возможностей при понимании необходимости быть активным, взрослым, принимать решение и отвечать за свои поступки (Е.А. Артюхова, 2017). Обретение связи с некой микросредой, организуемой в школе, каковой является коллектив волейбольной команды, - это дополнительная связь с учебным заведением, формирование положительного отношения к учебному процессу, понимание роли школы в жизни подростка, поскольку в ее стенах проходят и организуются секционные занятия. В референтной же группе, каковой может 
стать команда, создаются условия для социальной адаптации через формирование ценностей, стереотипов поведения, накопление некого социального опыта (Э. Натанзон, 1973; Д.Б. Годовикова, 1989). Относительно постоянная и предсказуемая среда, где происходит общение со сверстниками, создает ощущение защищенности, позволяет подростку чувствовать себя увереннее. Стабильность состава группы также позволяет наблюдать за своими личностными изменениями относительно других и осознавать темпы своего развития (Т.С. Баранова, 2003; В.С. Агеев, 2003; Э. Эриксон, 2003). Важно, что подростки воспринимают общение как высоко значимую для себя деятельность только в том случае, когда оно происходит в референтной для них группе. Таким образом, чтобы сама деятельность была успешной, она должна происходить в той же социальной группе, где налажено комфортное общение. Учет данной смысловой зависимости выгоден и наиболее эффективен с педагогической точки зрения.

Необходимо отметить значение принадлежности к группе сверстников для формирования важных ценностей в подростковом возрасте. Сами ценности являются той моральной базой, на которой строятся потребности и мотивы личности девочки-подростка. Благодаря сформированной системе ценностей определяется некая системность поступков ребенка, намечается цельность многих качеств личности (Б.С. Волков, 2001). С одной стороны преследование группой одной цели обязывает ее участников определить относительно общую для себя ценностную базу. С другой - девочки, выбирающие для себя коллектив спортивной команды, несомненно, уже объединены общими для себя ценностями, как социальными, так и индивидуальными.

Значение социальных связей для подростка трудно переоценить. Что дает девочке подросткового возраста общение? По словам Д.А. Леонтьева без общения для подростка невозможно формирование ценностей (Д.А. Леонтьев, 1997). То есть ценность общения обусловлена потребностью в формировании всех остальных общественных идеалов. Буквально все процессы формирования личности подростка выстраиваются вокруг общения. Насколько значимы в этом плане занятия в секции по волейболу? Здесь надо отметить, что спорт, а в особенности командный, может стать толчком для приобретения друзей, помочь избежать одиночества - часто возникающего чувства у подростка и весьма пагубно сказывающегося на дальнейшем развитии личности многих детей. Известно, например, что наиболее болезненно переживают одиночество 
именно девочки. Они детально и эмоционально описывают свое душевное состояние в моментах, когда испытывают одиночество (С.В.Малышева, 2003). Девочки-подростки, утверждающие, что их часто посещает чувство одиночества, отличаются негативными оценками себя и своих сверстников. Такие дети более безучастны, склонны к вредным привычкам (алкоголь, курение, наркотики), особенно эмоциональны, импульсивны, негативно относятся к культуре (культурным событиям, произведениям искусства, личностям, имеющим отношение к культуре), чем их сверстники, не испытывающие чувство одиночества. В дополнение, девочки-подростки при частом переживании чувства одиночества негативно относятся к самому состоянию одиночества, которое в некоторой степени может быть полезным, недостаточно высоко оценивают обучаемость, коммуникабельность, принципиальность, отличаются непринятием себя. Словом, чувство одиночества часто является негативным фактором для формирования характера девочки (С.В.Малышева, 2003; А.Р. Атласова, 2016). Следовательно, обретение друзей и ощущение причастности к группе может помочь сформировать в дальнейшем положительные качества личности. Общеизвестно, что понимание такой пользы и перспективы для себя почти всегда является одним из главных мотивов прихода в спортивную секцию.

Еще одним мотивом начала занятий в секции по волейболу может стать желание быть занятым делом, используя его как средство ухода от мрачных мыслей, в том числе при переживании чувства одиночества. Уже после, в процессе занятий спортом и постоянно вступая в контакт со сверстниками, заводятся новые знакомства, появляются друзья. Не случайно «занятость подростка» является так называемой «панацеей» от различных поведенческих проблем, по мнению многих родителей подростков и педагогов, работающих с ними.

Также важно понимать, что быть участником спортивной команды, выступать на соревнованиях - это то, что представляет собой большой интерес для девочек подросткового возраста, поскольку появляется возможность приобретения определенного социально статуса или выполнение некой социальной роли. Определение своего социального статуса в спортивной команде - это, как роль на площадке, так и роль в коллективе (Ю.А. Коломейцев, 1984). Наиболее желаемыми ролями являются вхождение в основу команды (не сидеть на скамье запасных игроков) и быть в числе 
формальных и неформальных лидеров данной малой группы (не стать аутсайдерами). В этом плане спортивная команда предоставляет своим участникам довольно ясную перспективу на приобретение социального статуса, поскольку всем известно, что нужно для того, чтобы добиться спортивного результата (Е.П. Ильин, 2018).

\section{Список литературы}

1. Казанская В.Г. Подросток: трудности взросления: книга для психологов, педагогов, родителей. - 2-е издание, дополненное. - СанктПетербург: Питер, 2008. - 283 с.

2. Артюхова, Е.А., Бобченко, Т.Г. Эмоциональные состояния в подростковом возрасте // «Инновационная наука».- №05, 2017. - С.228-229.

3. Сидоркина, С.Л. Формирование социальной ответственности у подростков посредством социально значимой деятельности: дисс. ... канд. пед. наук.- Нижний Новгород, 2010. - 294 с.

4. Наумова, Е.М. Эффективность физкультурно-спортивной деятельности как фактора формирования личной организованности подростков / Е.М. Наумова // Ученые записки университета им. П.Ф. Лесгафта, 2016. - № 10. - С. 114-119.

5. Натанзон, Э. Изучение межличностных отношений в классном коллективе на практических занятиях по общей психологии // Тирасп. гос. пед. ин-т им. Т.Г. Шевченко. - Кишинев: Лумина, 1973. -28 с. 